\title{
Solubility of commercial milk protein concentrates and milk protein isolates
}

\author{
V. Sikand, ${ }^{*}$ P. S. Tong,${ }^{\star 1}$ S. Roy, $†$ L. E. Rodriguez-Saona, $\neq$ and B. A. Murray§ \\ ${ }^{*}$ Dairy Products Technology Center and \\ †Statistics Department, California Polytechnic State University, San Luis Obispo 93407 \\ ¥Department of Food Science and Technology, The Ohio State University, Columbus 43210 \\ $\S$ Teagasc Food Research Centre, Moorepark, Fermoy, Co. Cork, Ireland
}

\begin{abstract}
High-protein milk protein concentrate (MPC) and milk protein isolate (MPI) powders may have lower solubility than low-protein MPC powders, but information is limited on MPC solubility. Our objectives in this study were to (1) characterize the solubility of commercially available powder types with differing protein contents such as MPC40, MPC80, and MPI obtained from various manufacturers (sources), and (2) determine if such differences could be associated with differences in mineral, protein composition, and conformational changes of the powders. To examine possible predictors of solubility as measured by percent suspension stability (\%SS), mineral analysis, Fourier transform infrared (FTIR) spectroscopy, and quantitative protein analysis by HPLC was performed. After accounting for overall differences between powder types, \%SS was found to be strongly associated with the calcium, magnesium, phosphorus, and sodium content of the powders. The FTIR score plots were in agreement with \%SS results. A principal component analysis of FTIR spectra clustered the highly soluble MPC40 separately from the rest of samples. Furthermore, 2 highly soluble MPI samples were clustered separately from the rest of the MPC80 and MPI samples. We found that the 900 to $1,200 \mathrm{~cm}^{-1}$ region exhibited the highest discriminating power, with dominant bands at 1,173 and $968 \mathrm{~cm}^{-1}$, associated with phosphate vibrations. The 2 highly soluble MPI powders were observed to have lower $\kappa$-casein and $\alpha$-s1-casein contents and slightly higher whey protein contents than the other powders. The differences in the solubility of MPC and MPI were associated with a difference in mineral composition, which may be attributed to differences in processing conditions. Additional studies on the role of minerals composition on MPC80 solubility are warranted. Such a study would provide a greater understanding of factors associated with differences in solubility and can provide insight
\end{abstract}

Received April 22, 2011.

Accepted September 3, 2011.

${ }^{1}$ Corresponding author: ptong@calpoly.edu on methods to improve solubility of high-protein milk protein concentrates.

Key words: milk protein concentrate, milk protein isolate, solubility, mineral

\section{INTRODUCTION}

Milk protein concentrate (MPC) powders are manufactured by pasteurization, UF, and diafiltration, followed by water removal by vacuum evaporation and spray drying (Mistry and Hassan, 1991a). The protein content of MPC powders varies from 36 to $85 \%$, depending on the degree of UF and diafiltration (Babella, 1989). Because MPC powders have a wide range of protein content, they can be categorized into 3 main types: low-protein powder ( $\leq 40 \%$ protein content), medium protein powder (60-70\% protein content), and high-protein powder $(\geq 80 \%$ protein content).

The MPC manufacturing process increases protein concentration, depletes some mineral contents, and causes dissociation of individual $\mathrm{CN}$ from its micellar structures. Fragments from CN micelles can predispose the milk system to further protein-protein interactions during spray drying and affect the functionality of the product (Singh, 2007). These structural changes may contribute to slow rehydration of MPC powders. In addition, dissolution of high-protein powders is slower with increased storage time and temperature (Anema et al., 2006; Havea, 2006).

Milk protein concentrate with $\geq 80 \%$ protein content has been reported to exhibit poor reconstitution properties (Baldwin and Truong, 2007; Mimouni et al., 2009). The high-protein milk powders, such as milk protein concentrate with $80 \%$ protein content (MPC80) and micellar $\mathrm{CN}$, have been reported to have low solubility indices of 9.4 and $>14.0 \mathrm{~mL}$, respectively (Mistry and Hassan, 1991b; Schuck et al., 2007). The low solubility index indicates a high level of sedimentation at the bottom of the tube (referred to as insoluble material; Anema et al., 2006; Havea, 2006). Havea (2006) reported that MPC 85 powders stored at $20^{\circ} \mathrm{C}$ had $53 \%$ solubility after $2 \mathrm{~d}$ of storage. However, high solubility $(96 \%)$ was reported even after $7 \mathrm{wk}$ of storage of MPC85, where calcium content of UF skim milk retentate was partially 
replaced by sodium ions (Bhaskar et al., 2001). Thus, high solubility with low insoluble material in MPC and with low calcium was attributed to more electrostatic repulsive forces between the $\mathrm{CN}$ micelles.

The solubility of high-protein powders may be tailored by controlling physicochemical properties. Schuck et al. (2002) reported a slight improvement in rehydration time when mineral salts were dry blended with native phosphocaseinate powder. Babella (1989) reported that changes in the functional properties (solubility, fat emulsifying capacity, and water-holding capacity) of MPC occurred when mineral salt components bonded to the protein were manipulated by adding bases such as calcium hydroxide, potassium hydroxide, and sodium hydroxide. The solubility of MPC80 was shown to be enhanced from 63 to $100 \%$ by the addition of 50 to $150 \mathrm{mM} \mathrm{NaCl}$ during the diafiltration step of MPC manufacture (Gualco, 2011).

Over the years, different methods have been applied to measure the solubility of milk protein powders. One such method, Fourier-transform infrared (FTIR) spectroscopy, has been used to characterize conformational changes of protein in dairy products (Boye et al., 1996). FTIR spectroscopy was used to test differences in protein conformation of spray-dried MPC powder and to determine if such differences could be associated with nitrogen solubility (Kher et al., 2007). These authors could not predict solubility based on FTIR spectra. However, they reported a positive correlation between solubility and 4 wk of storage $\left(21^{\circ} \mathrm{C}\right)$ of MPC and also reported that conformational changes occurred in the proteins of these powders during the same period.

Another method, HPLC, has been used because of its sensitivity and accuracy to resolve differences in the major protein fractions quickly and with high resolution. The peak identification and quantification are based on calibration curves of purified proteins. Bordin et al. (2001) reported that HPLC is a robust method to quantify protein fractions when $\mathrm{CN}$ was mixed with different fractions of whey proteins. Thus, in our study, HPLC might give us insight into the amounts of different protein fractions among different MPC sources. Chromatograms and protein quantification can help us identify and compare individual protein fractions among MPC and MPI powders from different sources to see if any aggregation or dissolution of protein fractions occurs.

de Castro-Morel and Harper (2002) conducted a basic functionality survey on 37 commercial MPC samples collected from a variety of sources in 10 countries with protein content ranging from 41.5 to $90.2 \%$. A wide range of variation (20-90\%) was observed with respect to solubility. No overall correlation between protein content, solubility, viscosity, and emulsification was found. However, de Castro-Morel and Harper (2002) did observe a correlation between protein content, $\mathrm{pH}$, viscosity, and solubility in the 4 high-protein (82-86\%) MPC samples. These authors attributed the variation in the functionality of MPC to differences in the processing methods such as drying conditions. However, these authors did not study any association of minerals with solubility of MPC.

The usage of high-protein powder such as MPC 80 and MPI in the dairy industry is limited due to its poor solubility (de Castro-Morel and Harper, 2002; Havea, 2006). In many food applications, a complete and quick dispersion of milk protein powder is required at room temperature $\left(21 \pm 1^{\circ} \mathrm{C}\right)$. Solubility of MPC80 and MPI is an important primary functional property as it affects other functional properties such as emulsifying, gelling, and foaming. Thus, gaining a better understanding of the factors that may be associated with good or poor solubility could provide useful insights to identify approaches that can be used to ensure high solubility of MPC for food applications.

The objectives of this project were (1) to characterize the solubility by evaluating commercially available MPC40, MPC80, and MPI powders from different sources in the US market and (2) to determine if an association exists between solubility, mineral composition, and protein conformation. The data from this work could be used to design studies that would better explain the role of minerals to improve the solubility of MPC.

\section{MATERIALS AND METHODS}

Two to 3 bags of 11 commercially available MPC powders consisting of MPC40 samples $(n=2)$, MPC80 samples $(\mathrm{n}=4)$, and MPI samples $(\mathrm{n}=5)$ powders were obtained from different US manufacturers (sources) in the US market. These powders were further divided into smaller bags and kept in an airtight container at room temperature $\left(21 \pm 1^{\circ} \mathrm{C}\right)$. The total nitrogen (AOAC, 1995; 991.20: 33.2.11) and moisture content $(990.20 ; 33.2 .44)$ of these commercial samples is been shown in Table 1. The MPC and MPI samples were reconstituted to contain 3.5\% protein content. Further, these samples were stirred for $4 \mathrm{~h}$ at room temperature $\left(21 \pm 1^{\circ} \mathrm{C}\right)$ and then analyzed for solubility per percent suspension stability method.

The solubility of each powder was measured by measuring suspension stability; mineral analysis was conducted by inductively coupled plasma optical emission spectroscopy (ICP-OES; Perkin-Elmer Inc., Waltham, MA); protein conformational changes were performed by FTIR spectroscopy; and protein fractionation was achieved using HPLC. 


\section{Percent Suspension Stability}

The percent suspension stability (\%SS; Anema et al., 2006) is defined as the ratio between the TS content of the supernatant obtained after centrifugation of reconstituted sample at $700 \times g$ for $10 \mathrm{~min}$ to the TS content $(\mathrm{g})$ of the aqueous dispersion as described in the equation below:

$$
\% \mathrm{SS}=\frac{\text { TS content of supernatant }}{\mathrm{TS} \text { content of original dispersion }} \times 100 .
$$

\section{Mineral Analysis}

Mineral analysis for MPC, MPC40, MPC80, and MPI powders was done by ICP-OES (Perkin-Elmer Inc.). Prior to the sample analysis, a sample preparation step was performed by taking $1 \mathrm{~g}$ of sample, followed by acid digestion with $70 \%$ nitric acid (Certified ACS Plus; Fisher Scientific Co. LLC, Fair Lawn, NJ) in a heat-resistant digestion tube and digested using a DigiPREP HT 100 Digestion System (SCP Science, Champlain, NY) for $1 \mathrm{~h}$ at $90^{\circ} \mathrm{C}$. Samples were cooled slightly by adding $5 \mathrm{~mL}$ of Nanopure/18.2 Mohm resistant water (Simplicity; Millipore, Molsheim, France). Three milliliters of $30 \%$ hydrogen peroxide (Certified ACS; Fisher Scientific Co. LLC) was added followed by one-half hour more of digestion. These samples were cooled at room temperature $\left(21 \pm 1^{\circ} \mathrm{C}\right)$ and the final volume of these samples was brought to $25 \mathrm{~mL}$ with Nanopure water. The aqueous sample was injected into the sampler and analyzed by ICP-OES.

\section{FTIR Spectroscopy}

The spectral measurements of MPC and MPI were performed using a FTS 3500GXFTIR spectrometer (Varian Inc., Palo Alto, CA) equipped with a potassium bromide beam splitter and deuterated triglycine sulfate (DTGS) detector, operating at $8 \mathrm{~cm}^{-1}$ resolution. The analysis used an attenuated total reflectance accessory with a 3-reflection diamond crystal plate, providing a 3 -fold increase in sample response compared with the standard single-reflection crystal plate (MIRacle; Pike Technologies, Madison, WI). Spectra were displayed in terms of absorbance and viewed by using Win-IR Pro Software (version 3.4.2; Varian Inc.). The infrared spectra were obtained from 1,800 and $800 \mathrm{~cm}^{-1}$ and 64 scans were co-added per spectrum to enhance the signal-to-noise ratio. The absorbance spectrum was obtained by rationing the sample single-beam spectrum against that of a blank optical path (reference spectrum). The instrument was continuously purged with $\mathrm{CO}_{2}$-free dry air from a $\mathrm{CO}_{2} \mathrm{RP} 140$ dryer (Dominick
Table 1. Basic composition $( \pm \mathrm{SD})$ of commercial MPC40, MPC80, and MPI samples ${ }^{1}$

\begin{tabular}{lcc}
\hline $\begin{array}{l}\text { MPC type } \\
\text { (sample no.) }\end{array}$ & $\begin{array}{c}\text { Protein } \\
\text { content, } \%\end{array}$ & $\begin{array}{c}\text { Moisture } \\
\text { content, } \%\end{array}$ \\
\hline MPC40 (1) & $42.04 \pm 0.6$ & $3.78 \pm 0.18$ \\
MPC40 (2) & $41.51 \pm 1.0$ & $2.90 \pm 0.3$ \\
MPC80 (3) & $80.07 \pm 0.2$ & $2.3 \pm 0.02$ \\
MPC80 (4) & $80.98 \pm 1.2$ & $4.94 \pm 0.02$ \\
MPC80 (5) & $77.73 \pm 0.8$ & $7.98 \pm 0.14$ \\
MPC80 (6) & $81.71 \pm 0.5$ & $3.44 \pm 0.12$ \\
MPI (7) & $89.26 \pm 1.2$ & $3.90 \pm 0.11$ \\
MPI (8) & $88.36 \pm 0.7$ & $4.39 \pm 1.5$ \\
MPI (9) & $89.21 \pm 0.1$ & $6.05 \pm 0.30$ \\
MPI (10) & $89.12 \pm 1.0$ & $2.57 \pm 0.35$ \\
MPI (11) & $88.86 \pm 0.63$ & $5.72 \pm 1.92$ \\
\hline
\end{tabular}

${ }^{1} \mathrm{MPC} 40=$ milk protein concentrate $(\mathrm{MPC})$ with approximately $40 \%$ protein content; MPC $80=$ MPC with approximately $\geq 80 \%$ protein content; MPI $=$ milk protein isolate with $\geq 85 \%$ protein content.

Hunter Inc., Charlotte, NC). For each MPC and MPI powder sample analyzed, the experiment was repeated 5 times to determine sample-to-sample variability.

The spectra were exported in GRAMS.spc file format and imported into the multivariate statistics program Pirouette, for Windows Comprehensive Chemometrics Modeling Software, version 3.11 (Infometrix Inc. Bothell, WA). The spectra were derivatized using a 5-point polynomial-fit Savitzky-Golay function and normalized using the maximum normalization function. Soft independent modeling of class analogy (SIMCA) was used to generate clustering groups. Soft independent modeling of class analogy is a multivariate technique based on principal component analysis, which was used in this study to evaluate the ability of the attenuated total reflectance-infrared (ATR-IR) spectral data to discriminate among MPC and MPI samples (Dunn and Wold, 1995). In SIMCA, training sets are assigned to classes and a principle component model is generated for each class with distinct confidence regions within them (De Maesschalck et al., 1999). The performance of this method depends not only on the difference between classes, but also strongly on the training set for each class (Candolfi et al., 1999). The scores plot allows the visualization of clustering among samples (sample patterns, groupings, or outliers). Sample residuals and Mahalanobis distances were used for outlier diagnostics.

\section{HPLC}

Separation of proteins in reversed-phase HPLC analysis was performed (Visser et al., 1991) based on differences in hydrophobicity of the proteins. This approach has been used in other dairy systems (Bordin et al., 2001; Ferreira et al., 2001; Huppertz et al., 2004). Detection measurements were carried out by ultraviolet absorption at $214 \mathrm{~nm}$. 
The reversed-phase HPLC was performed using an Agilent Zorbax Poroshell 300A C18 $(2.1 \times 75 \mathrm{~mm})$ column (Agilent Technologies Inc., Santa Clara, CA). Solvent A consisted of acetonitrile, water, and trifluoroacetic acid in a ratio of 100:900:1; solvent B consisted of acetonitrile, water (Fisher Scientific, Pittsburgh, PA), and trifluoroacetic acid (Sigma, St. Louis, MO) in a ratio of 900:100:1. Elution was performed at $0.75 \mathrm{~mL} /$ min, with a linear gradient from $23 \%$ of solvent B at 0 min to $37 \%$ of solvent B after $10 \mathrm{~min}$, followed by another linear gradient to $45 \%$ after $23 \mathrm{~min}$, followed by $100 \%$ of solvent B at $27 \mathrm{~min}$, and back to $23 \%$ of solvent B at 28 min.

Samples were prepared by a small modification to the original method by dissolving samples in $20 \mathrm{mM}$ Bis-Tris Propane (Sigma) reducing buffer containing 7 $M$ urea (Sigma) and 0.5\% $\beta$-mercaptoethanol (Sigma). The samples were kept undisturbed at room temperature $\left(21 \pm 1^{\circ} \mathrm{C}\right)$ for $1 \mathrm{~h}$ and then diluted to have a final protein concentration of $2 \mathrm{mg} / \mathrm{mL}$.

Data was quantified and peak areas from a known amount of loaded samples were measured by developing standard curves. Two-milligram standard samples (Sigma) were resuspended in $400 \mu \mathrm{L}$ of distilled water and $1,600 \mu \mathrm{L}$ of denaturing buffer $(7 M$ urea $+20 \mathrm{mM}$ Bis-Tris propane, $\mathrm{pH} 7.5)$ and $5 \mu \mathrm{L} / \mathrm{mL}$ of mercaptoethanol were added. Samples were passed through a $0.22-\mu \mathrm{m}$ filter before analysis.

\section{Statistical Analysis}

Data were analyzed using a general linear model in Minitab version 15.1 (Minitab Inc., State College, PA). We used \%SS as the response variable. In the mineral analysis section, the predictors were powder type and amount of mineral in the sample. The predictors used in the HPLC analysis were powder type, CN, and whey protein fractions. Cluster analysis was performed in $\mathrm{R}$ (a programming language that is used extensively for statistical analyses) to create groupings of the samples, based on their properties. Complete-linkage clustering was used, with the minimum distance between clusters as the distance measure. All of the experiments were performed in triplicate.

\section{RESULTS AND DISCUSSION}

\section{Suspension Stability}

The commercially obtained samples were tested for solubility by \%SS. Figure 1 shows the \%SS for the 11 samples. The solubility for MPC40 powders was observed to be higher as compared with MPC80, which, on average, showed \%SS between 23 and $42 \%$. The high- est variability in \%SS was observed in the MPI group, showing values ranging from 33 to $98 \%$. Two MPI powders were approximately 98 to $99 \%$ soluble. From the \%SS data, it appears that MPC40 samples are far more soluble compared with MPC80 and MPI samples, except MPI samples 9 and 10. Our observations are in agreement with de Castro-Morel and Harper (2002). These researchers reported low solubility $(32-48 \%)$ of high-protein powders with protein contents ranging from 82 to $86 \%$. Poor solubility for MPC80 and micellar $\mathrm{CN}$ has been attributed to a poor rate of water transfer into the high-protein milk powders as compared with reconstituted milk from low-heat nonfat dry milk powder during rehydration (Schuck et al., 1994; Mimouni et al., 2010). To investigate the solubility discrepancies between MPC80 and MPI powders compared with MPC40 powders, we carried out mineral, FTIR, and HPLC analyses.

\section{Mineral Analysis}

The mineral composition of various MPC40, MPC80, and MPI powders are presented in Table 2. The total mineral content for MPC40 was found to be higher than MPC80 and MPI. In addition, it was clear that low-protein powders (MPC40) had significantly higher levels of potassium as compared with high-protein powders (MPC80 and MPI). The low potassium content of high -protein powders may be attributed to a high rate of washing process (diafiltration) to achieve highprotein content; however, calcium depletion seems to be less sensitive to diafiltration, as milk protein content is associated with calcium content. We observed that sam-

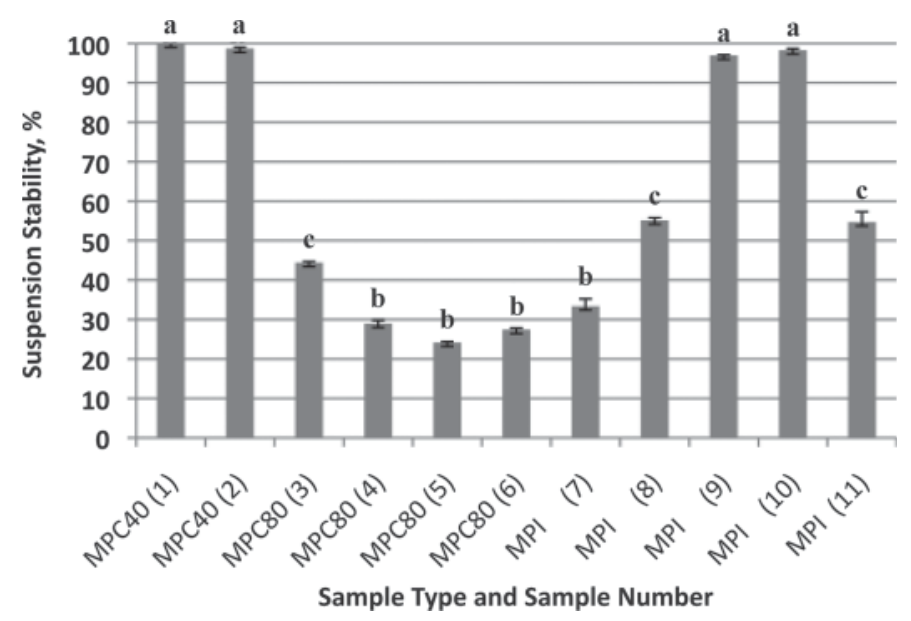

Figure 1. Effect of powder type on percent suspension stability. MPC40 = milk protein concentrate (MPC) with approximately $40 \%$ protein content; MPC80 = MPC with approximately $80 \%$ protein content; $\mathrm{MPI}=$ milk protein isolate with $\geq 85 \%$ protein content. Samples having different letters $(\mathrm{a}-\mathrm{c})$ are significantly different. 
Table 2. Mineral analysis of selected commercial milk protein concentrate (MPC) and milk protein isolate $($ MPI) samples $(\mathrm{n}=3)$

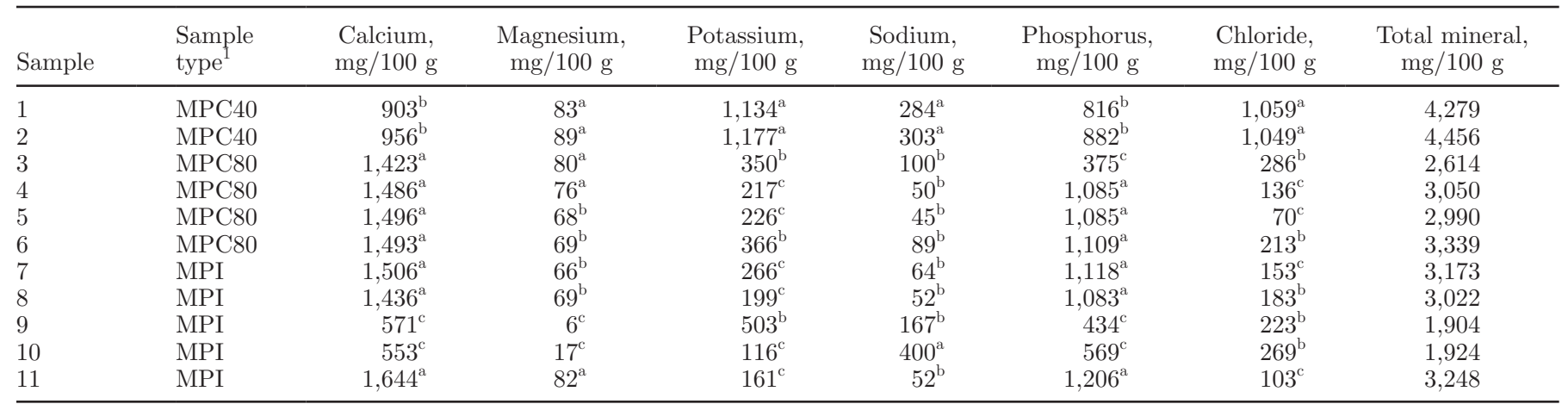

${ }^{a-c}$ Samples with different superscript letters are different (relative to those sharing the same letter) using complete linkage clustering, with minimum distance between clusters as a distance measure.

${ }^{1} \mathrm{MPC} 40=\mathrm{MPC}$ with approximately $40 \%$ protein content; MPC $80=\mathrm{MPC}$ with approximately $80 \%$ protein content; MPI $=$ MPI with $\geq 85 \%$ protein content.

ples 9 and 10 had increased levels of monovalent cations and decreased levels of divalent cations as compared with other MPC80 and MPI samples. These differences in MPI samples 9 and 10 contained roughly one-third the calcium as compared with other MPC and MPI samples, and they had a proportional decrease in phosphorus content. Sample 9 displayed higher potassium content, whereas sample 10 displayed higher sodium content. Table 2 shows letter groupings based on cluster analysis in $\mathrm{R}$, where values with different letters are statistically significantly different. In addition, we ran 6 ANOVA models with \% SS as the outcome of interest, powder type (MPC40, MPC80, and MPI) as a factor, and the amount of mineral (mg/100 g of powder), for each of the 6 minerals separately, as a covariate. Due to multicollinearity between the mineral contents, we did not put the contents for all of the minerals in 1 ANOVA. Each time we found that powder type was a significant predictor of \%SS $(P \leq 0.05)$. After accounting for powder type, the amount of calcium $(P<0.001)$, magnesium $(P=0.004)$, and phosphorus $(P=0.003)$ were found to have a significant negative association with \%SS, on average. In other words, after accounting for differences between powder types, samples with lower calcium, magnesium, and phosphorus content were observed to have higher \%SS. We also found that, after accounting for differences between powder types, samples with higher sodium content were observed to have higher \%SS $(P=0.007)$. Table 3 shows correlation coefficients between solubility of powder type and minerals. From these results, it appears that the high solubility of samples 9 and 10 may be associated with their calcium and phosphorus contents, which were lower than those of other samples, and also to the potassium content for sample 9, which was higher than the other samples. Therefore, mineral content may be tailored by the manufacturers to enhance the solubility of some high-protein powders. Bhaskar et al. (2001) found improved solubility of MPC in cold water by partial replacement of calcium in ultrafiltered retentate by sodium ions. Gualco (2011) found that enhanced solubility of MPC80 powder could be achieved by adding 50 to $150 \mathrm{mM} \mathrm{NaCl}$ during the diafiltration stage.

Mineral salts, although a minor component of milk have been known to contribute significantly toward functional properties. Schuck et al. (2002) reported that the quality of the powder is dependent on the mode of adding mineral salt. These authors observed that if mineral salt was added before spray drying, the process resulted in destructuring micellar $\mathrm{CN}$ and if mineral salt was added during dry mixing, it avoided the destructuring of CN micelles. Minerals play an important role in the CN micelle structural changes (Famelart et al., 1996) and can affect functional properties, such as water transfer during drying (Schuck et al., 1999) and, thus, increase the solubility of high-protein powders such as MPC80 or MPI.

\section{HPLC Analysis}

The protein distribution in milk is typically 75 to $80 \% \mathrm{CN}$ and 20 to $25 \%$ whey proteins. The milk $\mathrm{CN}$ consists mainly of $\alpha-\mathrm{CN}\left(\alpha_{\mathrm{S} 1}, \alpha_{\mathrm{S} 2}\right), \beta-\mathrm{CN}$, and $\kappa-\mathrm{CN}$, whereas the whey protein consists mainly of $\beta-\mathrm{LG}$

Table 3. Correlation coefficients for mineral content versus percent suspension solubility (SS) for milk protein concentrate 80 (MPC80) and milk protein isolate (MPI) samples

\begin{tabular}{lccrr}
\hline Sample type & $\mathrm{Na}$ & $\mathrm{Ca}$ & \multicolumn{1}{c}{$\mathrm{Mg}$} & \multicolumn{1}{c}{$\mathrm{P}$} \\
\hline SS for MPC80, \% & 0.59636 & -0.97863 & 0.85486 & -0.95667 \\
SS for MPI, \% & 0.78853 & -0.93947 & -0.90081 & -0.93012 \\
\hline
\end{tabular}

${ }^{1} \mathrm{MPC} 80=$ milk protein concentrate with approximately $80 \%$ protein content; MPI $=$ MPI with $\geq 85 \%$ protein content. 
Table 4. Calculated percent relative peak ratio of each protein fraction for representative milk protein concentrate (MPC40 and MPC80) and milk protein isolate (MPI) samples ${ }^{1}$

\begin{tabular}{|c|c|c|c|c|c|c|c|c|c|c|}
\hline Sample & $\begin{array}{l}\text { Sample } \\
\text { type }\end{array}$ & $\kappa-\mathrm{CN}$ & $\alpha_{\mathrm{S} 2^{-}} \mathrm{CN}$ & $\alpha_{\mathrm{S}^{-}-\mathrm{CN}}$ & $\beta-\mathrm{CN}$ & $\alpha-\mathrm{LA}$ & $\beta-\mathrm{LG} \mathrm{A}$ & $\beta-\mathrm{LG} \mathrm{B}$ & $\begin{array}{c}\mathrm{CN} \\
\text { content }\end{array}$ & $\begin{array}{l}\text { Whey } \\
\text { content }\end{array}$ \\
\hline 1 & MPC40 & $11.4^{\mathrm{a}}$ & $7.14^{\mathrm{b}}$ & $37.79^{\mathrm{a}}$ & $32.25^{\mathrm{a}}$ & $2.32^{\mathrm{b}}$ & $4.35^{\mathrm{b}}$ & $4.73^{\mathrm{b}}$ & 88.67 & 11.32 \\
\hline 3 & MPC80 & $10.24^{\mathrm{a}}$ & $6.67^{\mathrm{b}}$ & $38.35^{\mathrm{a}}$ & $34.07^{\mathrm{a}}$ & $0.95^{\mathrm{b}}$ & $5.61^{\mathrm{b}}$ & $4.09^{\mathrm{b}}$ & 89.34 & 10.65 \\
\hline 6 & MPC80 & $9.93^{\mathrm{a}}$ & $7.76^{\mathrm{b}}$ & $38.15^{\mathrm{a}}$ & $31.98^{\mathrm{a}}$ & $1.84^{\mathrm{b}}$ & $5.51^{\mathrm{b}}$ & $4.82^{\mathrm{b}}$ & 87.82 & 12.17 \\
\hline 8 & MPI & $11.51^{\mathrm{a}}$ & $8.01^{\mathrm{b}}$ & $36.43^{\mathrm{a}}$ & $32.99^{\mathrm{a}}$ & $1.53^{\mathrm{b}}$ & $5.06^{\mathrm{b}}$ & $4.48^{\mathrm{b}}$ & 88.93 & 11.06 \\
\hline 9 & MPI & $6.66^{\mathrm{b}}$ & $4.66^{\mathrm{c}}$ & $30.42^{\mathrm{b}}$ & $26.36^{\mathrm{b}}$ & $7.74^{\mathrm{a}}$ & $10.53^{\mathrm{a}}$ & $13.64^{\mathrm{a}}$ & 68.1 & 31.89 \\
\hline
\end{tabular}

${ }^{\mathrm{a}-\mathrm{c}}$ Samples with different superscript letters are different (relative to those sharing the same letter) using complete linkage clustering, with minimum distance between clusters as a distance measure.

${ }^{1}$ MPC40 $=$ milk protein concentrate with approximately $40 \%$ protein content; MPC $80=$ MPC with approximately $80 \%$ protein content; MPI $=$ MPI with $\geq 85 \%$ protein content.

( $\beta$-LG A and $\beta$-LG B) and $\alpha$-LA. Reversed-phase HPLC was performed on MPC and MPI samples. It was observed that sample 9, an MPI powder, had the highest whey protein content, followed by sample 10, also an MPI powder, as compared with the rest of the MPI and MPC samples from different sources (Table 4 ), although overall, lower whey protein contents in all MPC and MPI samples (except sample 9 and 10) were observed when compared with raw milk (CN-to-whey ratio 80:20). This may be due to the heat load applied during processing and, as a result, whey protein aggregates were bound to the $\mathrm{CN}$ micelles.

We ran a separate ANOVA for each of the percent $\mathrm{CN}$ and whey protein contents as covariates, powder type as a factor, and \% SS as the response variable. It is worth noting that we did not have HPLC information on samples 2, 4, and 7 and that these samples were not used in the ANOVA. Figures $2 \mathrm{a}$ and $2 \mathrm{~b}$ show \% SS versus $\mathrm{CN}$ and whey protein content, separated by powder types.

After accounting for differences between powder types, \%SS was negatively associated with $\kappa$-CN content $(P=0.07)$ and $\alpha_{S 1}$ content $(P=0.02)$. Thus, it is not surprising that the 2 MPI powders (samples 9 and 10 from Figure 1), were observed to have lower $\kappa-\mathrm{CN}$ and $\alpha_{S 1}$ content than all of the other powders, except for the MPC40 powder (sample number 1 from Figure 1 ), which was found to be highly soluble. Higher $\kappa-\mathrm{CN}$ content was observed in MPC85 powder after $3 \mathrm{~d}$ of storage at $50^{\circ} \mathrm{C}$ due to glycosylation (Anema et al., 2006). Lower $\kappa$-CN levels in sample 9 and 10 might be responsible for high solubility due to structural changes in the CN micelles because of low calcium levels and high monovalent salt (Schuck et al., 1999). Tessier and Rose (1964) reported that addition of $\mathrm{NaCl}$ in milk resulted in partial solubilization of $\kappa-\mathrm{CN}$. The statistical analysis did not show a significant association between whey protein content and \%SS.

\section{FTIR Analysis}

The FTIR score plots showed results very similar to \%SS results discussed earlier. When all MPC powders from each source were compared, the 2 highly soluble MPI powders (samples 9 and 10) were grouped separately from the rest of the MPC80 and MPI powders (Figure 3). Furthermore, upon exclusion of the MPC40 group, we observed that, besides samples 9 and 10, an MPC80 powder (sample 3) grouped separately from the rest of the MPC80 powders (samples 4, 5, and 6) and MPI powders (samples 7, 8, and 11). Interestingly, sample 3, an MPC80 powder, showed higher solubility with higher chloride and lower phosphorus contents than the other MPC80 powders. We found that the 900 to $1,200 \mathrm{~cm}^{-1}$ region exhibited the highest discriminating power, with dominant bands at $1,173 \mathrm{~cm}^{-1}$ and 968 $\mathrm{cm}^{-1}$ associated with phosphate vibrations. Our results are in agreement with Kher et al. (2007), who reported that MPC powders prepared with different methods were able to be separated on score plots, but with no changes in the amide spectral region. The separation based on score plots could not be related to solubility of samples. Furthermore, these authors reported that during storage $\left(4 \mathrm{wk}\right.$ at $21^{\circ} \mathrm{C}$ ) of these powders, solubility could be correlated to FTIR spectral changes.

It is evident from results presented here that a wide range of variability exists within the same powder type obtained from various manufacturers (sources). Solubility of powders is definitely influenced by mineral composition. Differences in the composition of MPC and MPI do not appear to affect protein conformational changes. But these differences can be easily captured by principal component analysis score plots.

\section{CONCLUSIONS}

The MPC powders obtained from the US market showed lot of variability in solubility. Within high- 
SIKAND ET AL.
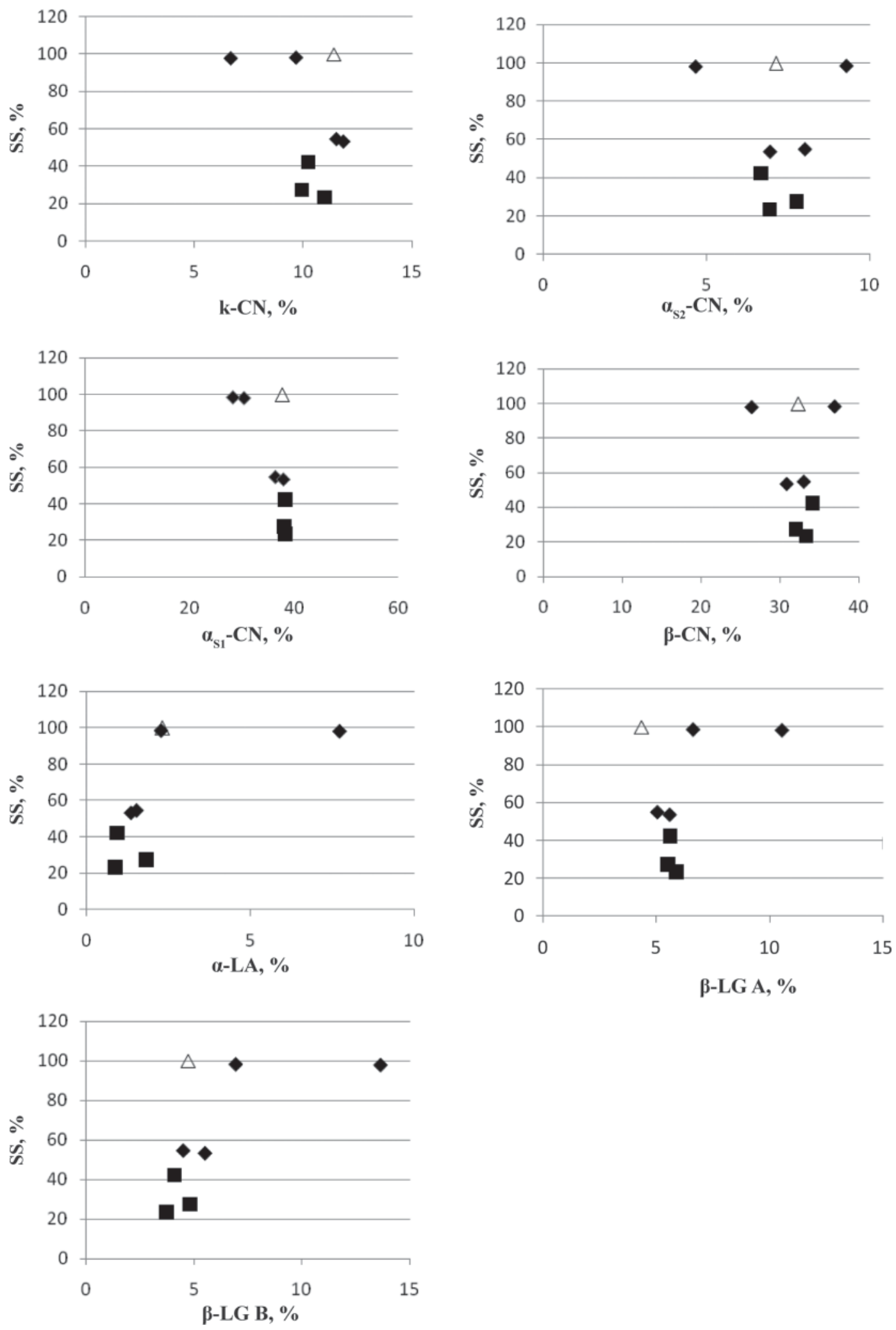

Figure 2. Effect of percent protein fraction content (CN or whey protein) on the percent suspension solubility (SS) pattern for MPC40 (milk protein concentrate with approximately $40 \%$ protein content; $\Delta$; sample 1), MPC80 (MPC with approximately $80 \%$ protein content; $\mathbf{\square}$; samples 3,4 , and 5), and MPI (milk protein isolate with $\geq 85 \%$ protein content; ; samples 8, 9, and 10). 


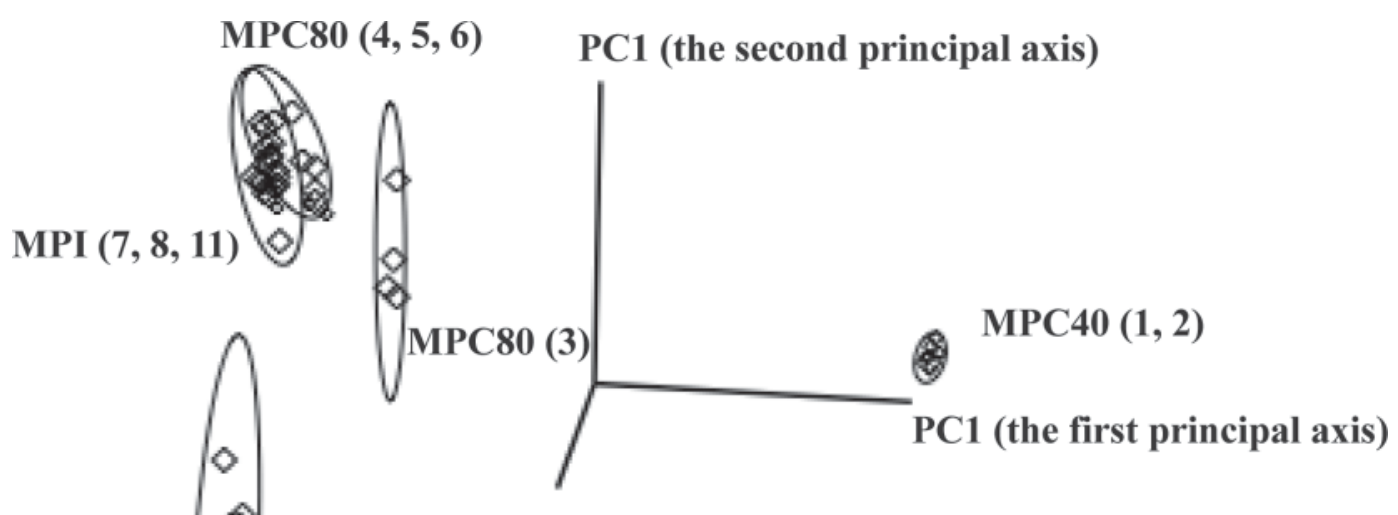

PC3 (the third principal axis)

Figure 3. Principal component analysis of milk protein concentrate (MPC) and milk protein isolate (MPI) samples by Fourier-transform infrared (FTIR) spectroscopy. MPC40 $=$ MPC with approximately $40 \%$ protein content; MPC $80=$ MPC with approximately $80 \%$ protein content; $\mathrm{MPI}=\mathrm{MPI}$ with $\geq 85 \%$ protein content; $\mathrm{PC}=$ principal component. The numbers in parentheses are the sample numbers.

protein milk powders such as MPC80 and MPI, solubility, as measured by \%SS, had a significant positive correlation with sodium content $(P=0.007)$ and lower calcium $(P<0.001)$, magnesium $(P=0.004)$, and phosphorus $(P=0.003)$ content (Table 3$)$. Based on our results, we found that variations in the MPC mineral composition may be a contributing factor to solubility. However, other factors, such as age of the powders, storage temperature, and processing temperature conditions should be included in any future study of approaches to improve solubility by modifications of minerals to clarify the observed relationships.

\section{ACKNOWLEDGMENTS}

The authors acknowledge Dairy Research Institute (Rosemont, IL) and California Dairy Research Foundation (Davis, CA) for their financial support. We thank the commercial dairy ingredient manufacturers for providing MPC samples.

\section{REFERENCES}

Anema, S. G., D. N. Pinder, R. J. Hunter, and Y. Hemar. 2006. Effects of storage temperature on the solubility of milk protein concentrate (MPC85). Food Hydrocoll. 20:386-393.

AOAC. 1995. Official Methods of Analysis. Vol. I. 16th ed. Association of Official Analytical Chemists, Gaithersburg, MD.

Babella, G. 1989. Scientific and practical results of the application of ultrafiltration. Tejipar 39:17-29.
Baldwin, A. J., and G. N. T. Truong. 2007. Development of insolubility in dehydration of dairy milk powders. Food Bioprod. Process. $85: 202-208$.

Bhaskar, G. V., H. Singh, and N. D. Blazey. 2001. Milk protein concentrate products and process. International Patent Specification WO01/41578. Dairy Research Institute, Palmerstone North, New Zealand.

Bordin, G., F. C. Raposo, B. de la Calle, and A. R. Rodriguez. 2001. Identification and quantification of major bovine milk proteins by liquid chromatography. J. Chromatogr. A 928:63-76.

Boye, J. I., A. A. Ismail, and I. Alli. 1996. Effects of physicochemical factors on the secondary structure of $\beta$-lactoglobulin. J. Dairy Res. 63:97-109.

Candolfi, A., R. De Maesschalck, D. L. Massart, P. A. Hailey, and A. C. E. Harrington. 1999. Identification of pharmaceutical excipients using NIR spectroscopy and SIMCA. J. Pharm. Biomed. Anal. 19:923-935.

de Castro-Morel, M., and W. J. Harper. 2002. Basic functionality of commercial milk protein concentrates. Milchwissenschaft 57:367370.

De Maesschalck, R., A. Candolfi, D. L. Massart, and S. Heuerding. 1999. Decision criteria for soft independent modeling of class analogy applied to near infrared data. Chemom. Intell. Lab. Syst. 47:65-77.

Dunn, W., and S. Wold. 1995. SIMCA pattern recognition and classification. Pages 179-193 in Chemometric Methods in Molecular Design. VCH Publishers, New York, NY.

Famelart, M. H., F. Lepesant, F. Gaucheron, Y. Le Graet, and P. Schuck. 1996. pH-induced physicochemical modifications of native phosphocaseinate dispersions: Influence of aqueous phase. Lait $76: 445-460$.

Ferreira, I. M. P. L. V. O., E. Mendes, and M. A. Ferreira. 2001. HPLC/UV analysis of proteins in dairy products using a hydrophobic interaction chromatographic column. Anal. Sci. 17:499501.

Gualco, S. 2011. Effect of sodium chloride addition during diafiltration on the solubility of milk protein concentrate. MS Thesis. California Polytechnic State University, San Luis Obispo. 
Havea, P. 2006. Protein interactions in milk protein concentrate powders. Int. Dairy J. 16:415-422.

Huppertz, T., P. F. Fox, and A. L. Kelly. 2004. High pressure treatment of bovine milk: Effects on casein micelles and whey proteins. J. Dairy Res. 71:97-106.

Kher, A., P. Udabage, I. McKinnon, D. McNaughton, and M. A. Augustin. 2007. FTIR investigation of spray-dried milk protein concentrate powders. Vib. Spectrosc. 44:375-381.

Mimouni, A., H. C. Deeth, A. K. Whittaker, M. J. Gidley, and B. R. Bhandari. 2009. Rehydration process of milk protein concentrate powder monitored by static light scattering. Food Hydrocoll. 23:1958-1965.

Mimouni, A., H. C. Deeth, A. K. Whittaker, M. J. Gidley, and B. R. Bhandari. 2010. Investigation of the microstructure of milk protein concentrate powders during rehydration: Alterations during storage. J. Dairy Sci. 93:463-472.

Mistry, V. V., and H. N. Hassan. 1991a. Delactosed, high milk protein powder. 1. Manufacture and composition. J. Dairy Sci. 74:11631169.

Mistry, V. V., and H. N. Hassan. 1991b. Delactosed, high milk protein powder. 2. Physical and functional properties. J. Dairy Sci. $74: 3716-3723$
Schuck, P., V. Briard, S. Méjean, M. Piot, M. H. Famelart, and J. L. Maubois. 1999. Dehydration by desorption and by spray drying of dairy proteins: Influence of the mineral environment. Drying Technol. 17:1347-1357.

Schuck, P., A. Davenel, F. Mariette, V. Briard, S. Méjean, and M. Piot. 2002. Rehydration of casein powders: Effects of added mineral salts and salt addition methods on water transfer. Int. Dairy J. $12: 51-57$.

Schuck, P., S. Mejean, A. Dolivet, C. Gaiani, S. Banon, J. Scher, and R. Jeantet. 2007. Water transfer during rehydration of micellar casein powders. Lait 87:425-432.

Schuck, P., M. Piot, S. Méjean, Y. Le Graet, J. Fauquant, G. Brulé, and J. L. Maubois. 1994. Spray-drying of native phosphocaseinate obtained by membrane microfiltration. Lait 74:375-388.

Singh, H. 2007. Interactions of milk proteins during the manufacture of milk powders. Lait 87:413-423.

Tessier, H., and D. Rose. 1964. Influence of $\kappa$-casein and $\beta$-lactoglobulin on the heat stability of skim milk. J. Dairy Sci. 47:1047-1051.

Visser, S., C. J. Slangen, and H. S. Rollema. 1991. Phenotyping of bovine-milk proteins by reversed-phase high-performance liquidchromatography. J. Chromatogr. 548:361-370. 